Article

\title{
Incidence of Post-Operative Complications and Factors Influencing Their Occurrence in Patients with Sickle Cell Disease in a Low-Income Country: A Case Study of Cameroon
}

\author{
Dominique Djomo Tamchom ${ }^{1,2,3,4, *}$, Charlotte Eposse Ekoube ${ }^{5,6}$, Basile Essola ${ }^{2,5}$, Serge Nga Nomo ${ }^{7,8}$, \\ Fleur Samantha Benghiat ${ }^{2,9}$ and Luc Van Obbergh ${ }^{2,4}{ }_{\mathbb{D}}$
}

check for updates

Citation: Djomo Tamchom, D.; Eposse Ekoube, C.; Essola, B.; Nga Nomo, S.; Benghiat, F.S.; Van

Obbergh, L. Incidence of

Post-Operative Complications and Factors Influencing Their Occurrence in Patients with Sickle Cell Disease in a Low-Income Country: A Case Study of Cameroon. J. Clin. Med. 2022, 11, 780. https://doi.org/ $10.3390 / j \mathrm{~cm} 11030780$

Academic Editor:

Krzysztof Laudanski

Received: 27 November 2021

Accepted: 25 January 2022

Published: 31 January 2022

Publisher's Note: MDPI stays neutral with regard to jurisdictional claims in published maps and institutional affiliations.

Copyright: (c) 2022 by the authors Licensee MDPI, Basel, Switzerland. This article is an open access article distributed under the terms and conditions of the Creative Commons Attribution (CC BY) license (https:// creativecommons.org/licenses/by/ $4.0 /)$.
1 Faculty of Health Sciences, University of Buea, Buea 63, Cameroon

2 Faculty of Medicine, Free University of Brussels, 1070 Brussels, Belgium; basile.essola@ulb.ac.be (B.E.); samantha.benghiat@erasme.ulb.ac.be (F.S.B.); luc.van.obbergh@erasme.ulb.ac.be (L.V.O.)

3 Department of Anaesthesiology and Intensive Care, Douala Gynaeco-Obstetric and Paediatric Hospital, Douala 7072, Cameroon

4 Department of Anaesthesiology, Erasme Hospital, 1070 Brussels, Belgium

5 Faculty of Medicine and Pharmaceutical Sciences, University of Douala, Douala 2701, Cameroon; eekoubec@yahoo.fr

6 Sickle Cell Treatment Centre, Laquintinie Hospital, Douala 4035, Cameroon

7 Higher Institute of Medical Technology, Yaoundé 188, Cameroon; sergesvivier@yahoo.fr

8 Department of Anaesthesiology and Intensive Care, Essos Hospital Centre, Yaoundé 441, Cameroon

9 Department of Haematology, Erasme Hospital, 1070 Brussels, Belgium

* Correspondence: domidjomo@yahoo.fr or dominique.djomo.tamchom@ulb.be; Tel.: +237-67466-9260 or +32-465-621894

\begin{abstract}
This study aimed to analyse post-operative complications and possible factors influencing their occurrence in the management of patients with sickle cell disease in a low-income country. We prospectively collected data regarding the management of patients with sickle cell disease requiring anesthesia for surgery in 11 Cameroonian hospitals from 1 May 2019 to 30 April 2021. The data were analysed using descriptive statistics and a binary logistic regression was used to determine the dependence between the variables. A total of 124 patients with sickle cell disease were enrolled; 64 were male and 60 female, giving a sex ratio of 0.93 . The rate of post-operative complications was $23.4 \%(29 / 124)$ and the death rate was 3.2\% (4/124). The female subjects had more complications than the male subjects $p<0.05$. The number of vaso-occlusive crises experienced per year showed a significant impact on the occurrence of post-operative complications $p<0.05$. Laparoscopic surgery had fewer post-operative complications 5/46 (10.9\%) than laparotomy 14/43 (32.5\%). The surgical technique for the abdominal procedures had a significant impact on the occurrence of post-operative complications $p<0.05$. The type of surgery $(p=0.198)$ and the anaesthesia technique $(p=0.225)$ did not show a significant impact on the occurrence of post-operative complications. Particular attention should be paid to female patients with sickle cell disease as they are more likely to experience postoperative complications, as well as to the frequency of vaso-occlusive crises, which are also predictive of post-operative complications. Opting for laparoscopic surgery whenever possible would help to reduce post-operative complications.
\end{abstract}

Keywords: patient with sickle cell disease; anaesthesia; surgery; post-operative complications; incidence

\section{Introduction}

Sickle cell (SC) disease is the most common genetic pathology in the world [1]. About 200,000 people are born with this disease each year and the regions with the highest rates are Africa, the Mediterranean, and Asia, where its prevalence is estimated at 2 to $6 \%$ of the population [2]. In Cameroon, the prevalence of sickle cell traits is $22.3 \%$ and the prevalence 
of SS homozygous varies from $1.7 \%$ to $9 \%$, depending on the region [3]. Despite the complex pathophysiology and the diverse clinical picture, considerable progress has been made in the understanding and management of sickle cell disease [4]. Thanks to improved neonatal screening and treatment, many patients with sickle cell disease survive to adulthood and present themselves more frequently for surgery [2]. It is in this situation that the anaesthesiologist is concerned, especially since 15 to $30 \%$ of patients undergoing surgery suffer from post-operative complications [5-7]. Surgery exposes the sickle cell disease patient to an increased risk of disease-related complications [8], requiring meticulous perioperative clinical care, including adjusted anaesthesia management, which has been widely described. Most of the data are issued from western countries and only a few from the sub-Saharan area, where facilities are limited, even though they represent most of the SC patients undergoing surgery, suggesting that the data issued from the former countries could be biased $[7,9,10]$. Therefore, this study is crucial as it contributes to the body of research by analysing post-operative complications and possible factors influencing their occurrence in the perioperative management of sickle cell patients in a low-income country.

\section{Methods}

After obtaining the ethical clearances from our Institutional Ethics Committee and the National Ethics Committee for Research for Human Health (CNERSH), we prospectively collected data regarding the management of sickle cell patients requiring anesthesia for surgery in 11 Cameroonian hospitals from 1 May 2019 to 30 April 2021. The pre-determined data collection sheet was handled by anaesthesiologists working in hospitals (11) classified as levels 1 and 2 (the highest levels of the health pyramid in Cameroon), from $t$ pre-anaesthetic consultation to post-anaesthetic follow-up. Only facilities with at least one fully qualified anaesthesiologist were included, given the limited number of anaesthesiologists practicing throughout the territory, which was about 50 physicians per 25 million inhabitants in 2019. The classification of risk (minor, intermediate, and high) according to the type of surgery was performed and associated with each collection sheet.

All patients with major sickle cell syndrome (referring to more or less severe clinical manifestations, characterised by SS homozygosity and SC composite heterozygosity) admitted to one of the targeted health facilities, who had been under the care of an anaesthesiologist and had undergone surgery, were included in this study. The major sickle cell syndrome combines three main categories of clinical manifestations: chronic haemolytic anaemia; extreme susceptibility to infections; and vaso-occlusive phenomena. It differs from asymptomatic (AS) forms. Those who did not undergo surgery and those who withdrew their consent were excluded.

The characteristics of the patients with sickle cell disease were determined using the patients' medical records or by the patients' reports when records were not available. The post-operative complications that occurred were recorded as well. Post-operative complications were those that occurred between the end of surgery and post-operative discharge or those that required patients to return to the hospital within 15 days of discharge. Mortality was defined perioperatively. We then looked at the factors that could influence the occurrence of these complications in this study population. As already described, the data were collected on a previously determined sheet, and as such, the main variables were: regular treatment with Hydroxyurea, number of vaso-occlusive crises experienced per year, level of risk associated with surgery, pre-operative transfusion, length of hospital stay before surgery, type of surgery, duration of surgery, surgical technique, ASA classification, context of surgery, and type of anaesthesia. We used convenience sampling to obtain a size sample (Figure 1). 
Enrolment

Assessed for eligibility $(n=124)$

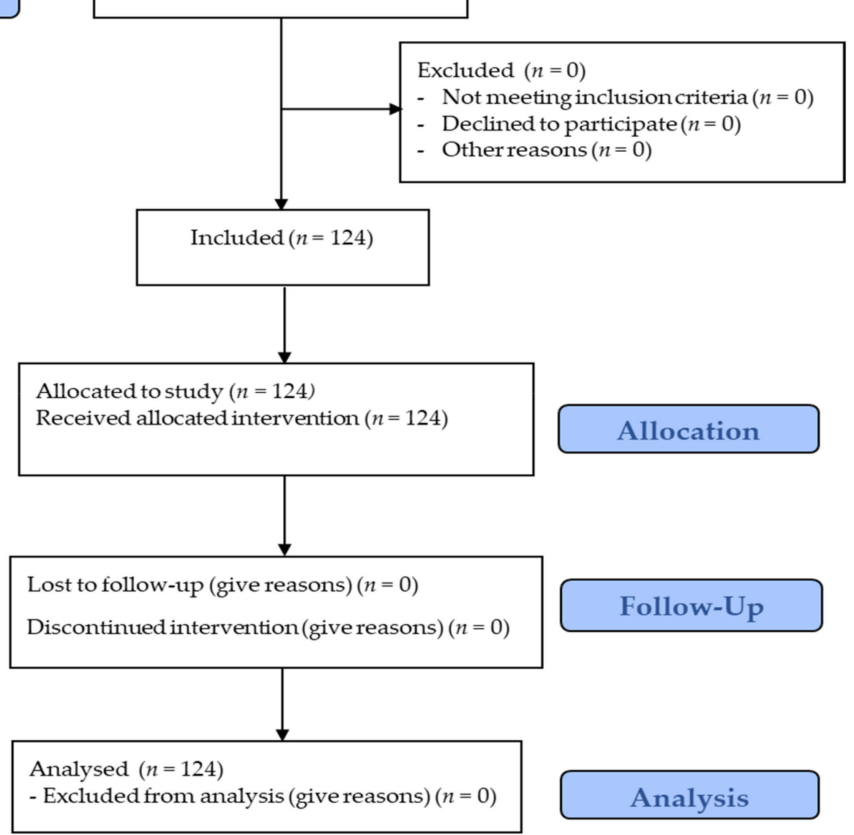

Figure 1. CONSORT 2010 Flow Diagram.

The statistical analysis was performed using IBM SPSS version 23 software (International Business Machines Corporation, New York state, USA). The results were expressed as a percentage number and as an average standard deviation and interval. Binary logistic regression was used to determine the dependence between the variables. The rules of thumb of the binary logistic regression for this study stats that significant variables have a significant impact on the occurrence of post-operative complications in a patient with sickle cell and variables that are not significant do not have a significant impact on the occurrence of post-operative complications. A value of $p<0.05$ represents a statistically significant dependence at the $5 \%$ level.

\section{Results}

A total of 124 patients with sickle cell disease were enrolled; 64 were male and $60 \mathrm{fe}-$ male, giving a sex ratio of 0.93 . The rate of post-operative complications was $23.4 \%(29 / 124)$ and the death rate was $3.2 \%(4 / 124)$. The mean age of the population was $20.5 \pm 7.1$ years, with a minimum and maximum of 5 and 47 years, respectively. The mean number of vaso-occlusive crises experienced per year was $2.1 \pm 1.1$, with a minimum and maximum vaso-occlusive crisis of 1 and 5 , respectively. The mean length of pre-operative hospital stay was $2.1 \pm 1.4$ days, with a minimum and maximum of 1-14 days, respectively. The other characteristics of the study population are listed in Table 1.

Considering the type of surgery in our overall study population, the rate of postoperative complications was higher after orthopaedic surgery $9 / 30(30 \%)$. Those who underwent laparoscopic surgery for abdominal procedures had fewer post-operative complications 5/46 (10.9\%) than those who underwent laparotomy 14/43 (32.5\%). Patients with sickle cell disease who received locoregional anaesthesia had more post-operative complications $12 / 41(29.3 \%)$ than those who received general anaesthesia 17/83 (20.5\%). 
Table 1. Characteristics of the study population.

\begin{tabular}{|c|c|c|}
\hline Total Number of Patients $=124$ & $\begin{array}{c}\text { Number } \\
(n)\end{array}$ & $\begin{array}{c}\text { Percentage } \\
(\%)\end{array}$ \\
\hline \multicolumn{3}{|l|}{ Genotype } \\
\hline SS & 112 & 90 \\
\hline $\mathrm{SC}$ & 12 & 10 \\
\hline \multicolumn{3}{|l|}{ Usual follow-up } \\
\hline Follow-up by a haematologist & 24 & 19.3 \\
\hline Follow-up by another physician & 44 & 35.5 \\
\hline On Hydroxyurea & 26 & 21 \\
\hline Pre-operative transfusion & 100 & 80.6 \\
\hline \multicolumn{3}{|l|}{ ASA classification } \\
\hline ASA2 & 101 & 81.5 \\
\hline ASA3 & 23 & 18.5 \\
\hline \multicolumn{3}{|l|}{ Type of anaesthesia } \\
\hline General anaesthesia & 83 & 67 \\
\hline Loco-regional anaesthesia & 41 & 33 \\
\hline \multicolumn{3}{|l|}{ Level of risk associated with surgery } \\
\hline Intermediate & 119 & 96 \\
\hline High & 5 & 4 \\
\hline \multicolumn{3}{|l|}{ Surgical context } \\
\hline Emergency surgery & 17 & 13.7 \\
\hline Elective surgery & 107 & 86.3 \\
\hline \multicolumn{3}{|l|}{ Type of surgery } \\
\hline Digestive surgery & 73 & 59 \\
\hline Orthopedic surgery & 30 & 24 \\
\hline Obstetrical surgery & 16 & 13 \\
\hline Otolaryngology surgery & 5 & 4 \\
\hline \multicolumn{3}{|l|}{ Surgical technique } \\
\hline laparotomy & 43 & 34.7 \\
\hline Laparoscopy & 46 & 37.1 \\
\hline Others & 35 & 28.2 \\
\hline \multicolumn{3}{|l|}{ Post-operative complications recorded } \\
\hline Fever & 16 & 13 \\
\hline Vaso-occlusive crisis & 15 & 12.1 \\
\hline Acute chest syndrome & 3 & 2.4 \\
\hline Deglobalization with severe anaemia & 5 & 4 \\
\hline Parietal suppuration & 5 & 4 \\
\hline Eclampsia of post-partum & 2 & 1.6 \\
\hline
\end{tabular}

Female subjects had more complications than male subjects $p<0.05$.

The number of vaso-occlusive crises experienced per year showed a significant impact on the occurrence of post-operative complications $p<0.05$.

The length of pre-operative hospital stay $(p=1)$ and pre-operative transfusion $(p=0.989)$ had no impact on the occurrence of post-operative complications.

Emergency surgery $(p=0.721)$ and anaesthesia technique $(p=0.225)$ did not have a significant impact on the occurrence of post-operative complications.

The type of surgery $(p=0.198)$ and the duration of surgery $(p=0.194)$ did not show a significant impact on the occurrence of post-operative complications.

The surgical technique used for the abdominal procedures had a significant impact on the occurrence of post-operative complications $(p<0.05)$.

The data from the logistic regression are presented in Table 2. 
Table 2. Logistic regression dependence between the variables.

\begin{tabular}{|c|c|c|c|c|c|c|}
\hline Variables & Coefficient & E.S & Wald & ddl & Sig. & $\operatorname{Exp}(B)$ \\
\hline Sex & $-1.431^{* *}$ & 0.579 & 6.104 & 1 & 0.013 & 0.239 \\
\hline On Hydroxyurea & -0.358 & 0.700 & 0.262 & 1 & 0.609 & 0.699 \\
\hline $\begin{array}{c}\text { Number of VOC } \\
\text { per year }\end{array}$ & $0.499 * *$ & 0.239 & 4.373 & 1 & 0.037 & 1.647 \\
\hline ASA classification & 0.338 & 0.792 & 0.182 & 1 & 0.670 & 1.402 \\
\hline $\begin{array}{l}\text { Emergency context } \\
\text { Length of }\end{array}$ & 0.291 & 0.813 & 0.128 & 1 & 0.721 & 1.338 \\
\hline $\begin{array}{l}\text { pre-operative } \\
\text { hospital stay }\end{array}$ & -22.550 & $40,192.717$ & 0.000 & 1 & 1.000 & 0.000 \\
\hline $\begin{array}{l}\text { Pre-operative } \\
\text { transfusion }\end{array}$ & -0.009 & 0.666 & 0.000 & 1 & 0.989 & 0.991 \\
\hline Type of surgery & 1.873 & 1.454 & 1.659 & 1 & 0.198 & 6.507 \\
\hline Surgical technique & $1.664^{* *}$ & 0.717 & 5.391 & 1 & 0.020 & 5.280 \\
\hline Anesthesia technique & -0.819 & 0.675 & 1.471 & 1 & 0.225 & 0.441 \\
\hline Duration of surgery & 0.027 & 0.021 & 1.684 & 1 & 0.194 & 1.028 \\
\hline Constant & 17.269 & $40,192.717$ & 0.000 & 1 & 1.000 & $31,620,578.337$ \\
\hline Classification Table & $81.5 \%$ & & & & & \\
\hline Loglikelihood & 108.697 & & & & & \\
\hline Cox and Snell R-square & 0.190 & & & & & \\
\hline Nagelkerke R-square & 0.287 & & & & & \\
\hline Khi-Square & 26.194 & & & & 0.051 & \\
\hline
\end{tabular}

\section{Discussion}

To the best of our knowledge, very few, if any, recent studies have addressed the issue of post-operative complications in patients with sickle cell disease in a diverse population of children and adults simultaneously and for a variety of surgical indications. This study showed that the post-operative complications and their incidences observed in carriers of major sickle cell syndrome in a resource-limited setting were no different from those seen elsewhere. Length of pre-operative hospital stay, pre-operative blood transfusion, emergency context, type of surgery, and type of anaesthesia did not have a significant impact on the occurrence of these complications. However, gender, number of vasoocclusive crises experienced per year, and surgical technique used influenced the occurrence of post-operative complications.

\section{Incidence of Post-Operative Complications in Sickle Cell Patients}

The post-operative period is particularly critical, with the highest incidence of complications [11]. The main complications (febrile episodes, haemolysis, vaso-occlusive crisis, thromboembolic accidents, and acute chest syndrome) are characterised by hypoxia, hypothermia, and pain $[12,13]$. Their incidence varies according to the type of procedure and the medical-surgical team. The treatment is based on adequate hydration, oxygen therapy, broad-purpose antibiotic therapy, or even erythrocyte transfusion. All these complications were observed in our series, independently of the type of surgery performed. The overall incidence of post-operative complications of $23.4 \%$ found here is close to that reported by some authors, although most of these authors dealt with only one type of surgery.

In the series of laparoscopic cholecystectomy in sickle-cell-disease adults performed between 1996 and 2006 in Saudi Arabia [14], 31/427 (7.3\%) of patients had complications, including 19/31 (4.5\%) vaso-occlusive seizures; $8 / 31$ (1.9\%) acute chest syndromes; $4 / 31$ $(0.9 \%)$ cases of superficial infection of the surgical wound; and no deaths. In another series of 42 laparoscopic cholecystectomies performed in Senegal [7] between 1998 and 2002, the overall rate of complications noted was $16.7 \%$, with 3 cases $(7.1 \%)$ of vaso-occlusive crises; 2 cases $(4.7 \%)$ of acute chest syndrome; $2(4.7 \%)$ cases of post-operative infection; and no deaths. In 138 orthopaedic procedures performed on 118 patients with sickle cell disease in a multicentre study [15], there was an overall rate of $67 \%$ of serious complications, and 
sickle cell events (acute chest syndrome or vaso-occlusive crisis) occurred in $17 \%$ of cases. Two patients $(1.7 \%)$ died following surgery. In a series of cholecystectomies in patients with sickle cell disease in Jamaica [16], the mortality rate was $7.4 \%$.

The results observed in these studies are comparable to ours, in which the complications recorded and their proportions are practically the same. However, it should be noted that there were no deaths in the Saudi Arabian and Senegalese cholecystectomy series. In the orthopaedic surgery multicentre series, the death rate was less than half of ours and in the Jamaican cholecystectomy series, the death rate was double ours. As already mentioned, the previous studies focused only on one type of surgery in patients with sickle cell disease. We included different indications for surgery to analyse the influence of this factor on the incidence of post-operative complications in patients with sickle cell disease.

\section{Elements That Did Not Have a Significant Impact on the Occurrence of Post-Operative Complications}

The pre-operative clinical condition of patients with sickle cell disease may require extensive preparation in advance, since these patients are admitted to hospital for elective surgery several days or weeks before the procedure. However, in our study, the length of pre-operative hospital stay was not a predictive factor for the occurrence of post-operative complications, where the maximum observed pre-operative length of stay was 2 weeks. This is in line with the results reported by some authors. A review of a series of patients with sickle cell disease who underwent cholecystectomy between 1978 and 1991 to assess their perioperative management and clinical outcome [17] showed that these patients were pre-operatively prepared over 2 to 8 weeks, and there were no apparent sickle cell-diseaserelated vaso-occlusive events or late complications.

Although there is currently no consensus on the benefit of pre-operative transfusion for patients with major sickle cell syndrome [18], their anaesthesia preparation frequently includes the transfusion of red blood cells to reduce the risk of morbidity and mortality associated with the procedure [19]. The purpose of blood transfusion in sickle cell disease is to rapidly decrease the proportion of red blood cells containing haemoglobin S, and thus to prevent harmful pathophysiological cascades. In a study conducted in a reference centre for genetic red blood cell diseases [18], on patients with major sickle cell disease syndrome who underwent cholecystectomy between January 2009 and March 2012, there was no difference in complication rates between the transfused and non-transfused groups. In a cohort of paediatric patients with sickle cell disease undergoing abdominal surgery [20], there was no clear association between post-operative complications and transfusion approach or pre-operative haematocrit level. These results are similar to those in our series. Controversy continues regarding whether and when (pre-operatively or post-operatively) patients with sickle cell disease should receive transfusions and which anaesthetic technique (regional or general) confers benefits [2].

The anaesthetic management of patients with sickle cell disease is well defined [4,21]. Compliance with safety rules is essential as in any form of anaesthesia, general or locoregional. No specific drug protocol is recommended. Our study showed more frequent use of general anesthesia in these patients. This could be due to the choices and habits of anaesthesiologists, but also to the predominant type of surgery, which was abdominal and, most frequently laparoscopic. However, $13 \%$ of the surgeries performed were caesarean sections.

Opinions still vary as to the choice of anaesthetic technique for a parturient with sickle cell disease. Camous et al., in a study to determine the impact of anaesthetic technique on the occurrence of postnatal complications related to sickle cell disease, suggested that general anaesthesia may be associated with post-natal sickle cell complications, even when the severity of the disease has been taken into account [22]. Bakri et al., on the other hand, suggested that spinal anaesthesia may have advantages over general anaesthesia in parturients with sickle cell disease undergoing caesarean section [23]. Loco-regional anaesthesia is of particular interest and could be recommended for caesarean anaesthesia 
because providing a sympathetic block leads to vasodilation and increased peripheral microcirculatory flow rates and, thus, probably prevents vaso-occlusive events. Despite this apparent advantage of loco-regional anaesthesia, in our study, we did not observe a statistically significant difference between this anaesthesia technique and general anesthesia in terms of the occurrence of post-operative complications, regardless of the type of surgery, although the patients who received locoregional anaesthesia had more post-operative complications than those who received general anaesthesia (Figure 2).

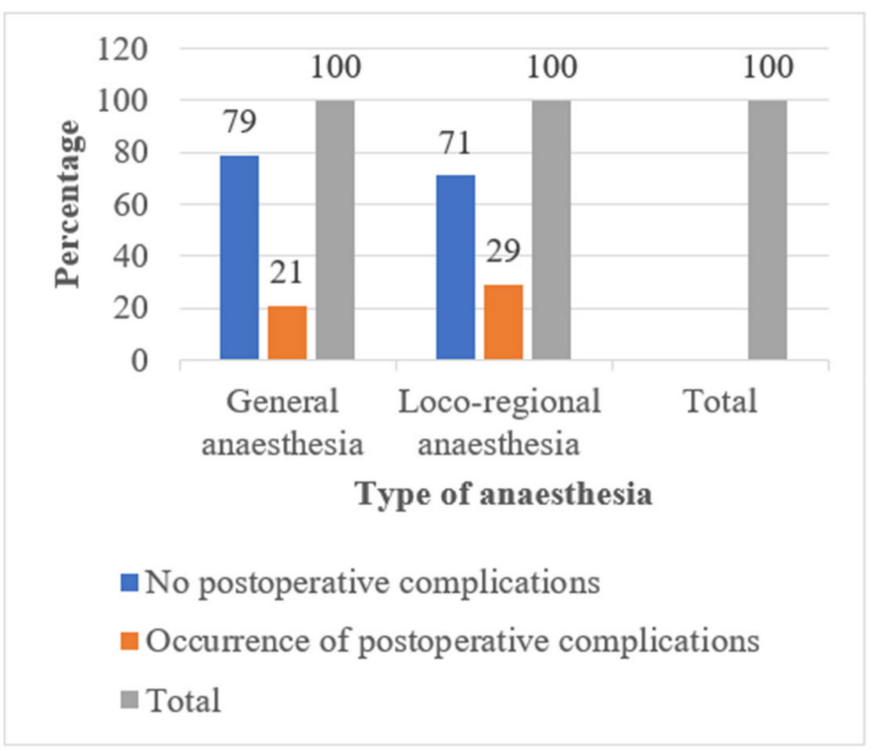

Figure 2. Incidence of post-operative complications according to the type of anaesthesia.

The type of surgery could also be associated with the risk of post-operative complications. Griffin et al. conducted a retrospective study of 54 children undergoing 66 elective surgical procedures without pre-operative blood transfusion, and 10 children undergoing 10 elective procedures with pre-operative blood transfusion, over 16 years [24]. They found that patients who underwent laparotomy, thoracotomy, or tonsillectomy and adenoidectomy had a higher risk of developing post-operative complications. Contrary to this study, in our series, the type of surgery after which there were the most post-operative complications was orthopaedic surgery. There was no significant difference in impact between the type of surgery and the occurrence of post-operative complications.

The perioperative risk for patients with sickle cell disease is thought to be greatly increased in an emergency setting. The urgent nature of the surgery associated with other factors, such as hypoxia, hypothermia, dehydration, acidosis, and pain, increases the incidence of sickling in red blood cells [13]. In a large cohort of paediatric patients (813) with sickle cell disease undergoing abdominal surgery, urgent surgical procedures had almost twice the risk of complications as elective procedures [20]. These results contrast with ours, in which the context of surgical urgency was not predictive of post-operative complications, although the frequency of urgent surgeries was almost similar, with $13.7 \%$ in ours and $13 \%$ in theirs.

\section{Elements That Had a Significant Impact on the Occurrence of Post-Operative Complications}

Once the diagnosis of sickle cell disease is made at any time, it is important to organize the modalities of follow-up and management [25], which are focused on hydration, vaccination, pneumococcal antibiotic prophylaxis with penicillin $\mathrm{V}$, systematic supplementation with folic acid, and hydroxycarbamide in case of repeated complications [26,27]. This follow-up could affect the patient's condition before surgery and most likely the occurrence of post-operative complications. A study conducted between January 2009 and March 
2012 on patients with sickle cell disease who had undergone cholecystectomy [18] showed that among the factors studied, a history of acute chest syndrome was associated with the occurrence of post-operative complications. In our study, the number of vaso-occlusive crises experienced per year was a significant predictor of the occurrence of post-operative complications. On one hand, this may imply that reducing the frequency of vaso-occlusive crises in patients with sickle cell disease should reduce the occurrence of post-operative complications but, on the other hand, this is also a warning that these patients should be more closely monitored post-operatively.

The surgical technique in our series was associated with post-operative complications, especially for abdominal surgical procedures. Patients who underwent laparoscopic surgery had fewer post-operative complications than those who underwent laparotomy (Figure 3). Laparoscopic surgery, particularly cholecystectomy, is considered a standard operative procedure, especially for gallstone disease (which is common in sickle cell disease). However, although many studies have been published on the benefits and complications of laparoscopic cholecystectomy in lithiasis cholecystitis [9,28-30], the evidence for the safety and efficacy of laparoscopy in the management of cholelithiasis in paediatric patients with sickle cell disease remains limited, and related controversies are unresolved. Moreover, laparoscopic surgery is not yet fully available in sub-Saharan African countries and training programs should be more intensively developed, which is now the case in Douala, Cameroon.

Our study had limitations. The types of surgery were varied in different proportions, and with different levels of risk. This could constitute a bias in the expression of certain characteristics of the less-represented procedures.

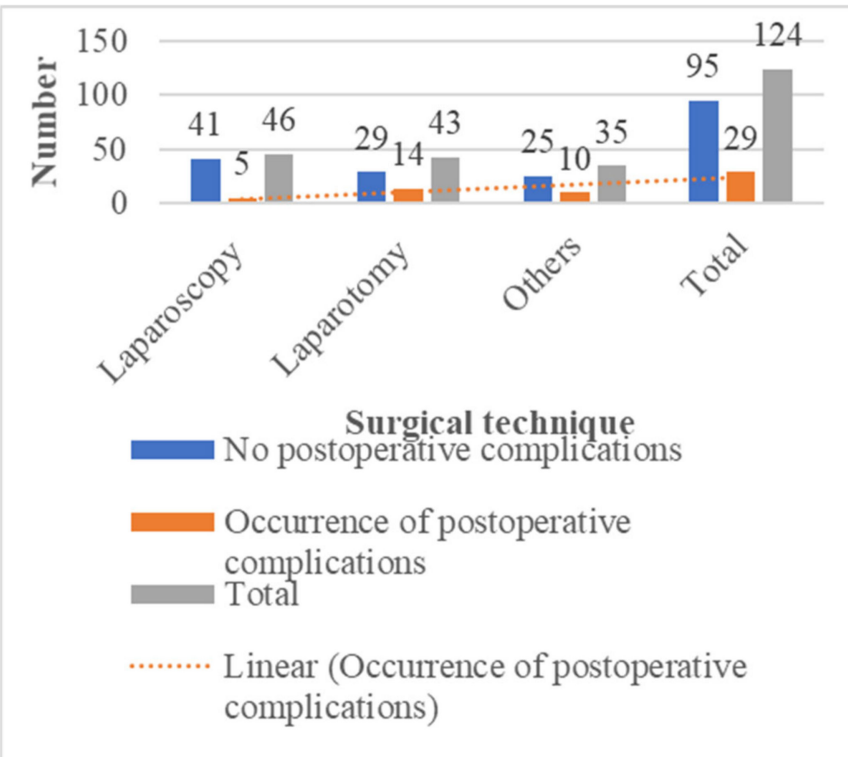

Figure 3. Incidence of post-operative complications according to surgical technique.

\section{Conclusions}

Sickle cell disease causes life-threatening complications in the peri-operative period and is of great interest to the anaesthetist. Although practices in the routine follow-up and perioperative management of sickle cell patients in resource-limited settings differ from those in high-resource settings, the incidence of post-operative complications and the complications encountered are not significantly different. Particular attention should be paid to female patients with sickle cell disease as they are more likely to experience post-operative complications, as well as to the frequency of vaso-occlusive crises, which are also predictive of post-operative complications. Pre-operative blood transfusion alone is not sufficient to reduce the occurrence of post-operative complications. Better management 
of sickle cell disease outside the acute phases, combined with the choice of laparoscopy as far as possible during abdominal surgical procedures, would make it possible to reduce the occurrence of post-operative complications.

Author Contributions: All authors were involved in the preparation of this manuscript. Conceptualization and writing — original draft preparation: D.D.T., L.V.O. and F.S.B.; methodology: D.D.T., C.E.E. and L.V.O.; investigations: D.D.T., C.E.E., S.N.N. and B.E.; data curation: D.D.T. and B.E.; formal analysis: D.D.T. and S.N.N.; writing—original draft: D.D.T. and L.V.O.; supervision: L.V.O. All authors have read and agreed to the published version of the manuscript.

Funding: This research was funded by the Belgian government via "Académie de Recherche et d'Enseignement Supérieur (ARES) de l'Université Libre de Bruxelles (ULB)", grant ref. " ARESPFS2016Cameroon » to J.S.

Institutional Review Board Statement: The study was conducted in accordance with the Declaration of Helsinki, and approved by the Institutional Ethics Committee of the Gynaecologic-Obstetric and Pediatric Hospital of Douala ( $\mathrm{N}^{\circ}$ 2019/0010/HGOPED/DG/CEI) and, the National Ethics Committee for Research for Human Health (CNERSH) N 2019/10/1196/CE/CNERSH/SP.

Informed Consent Statement: Informed consent was obtained from all subjects involved in the study.

Acknowledgments: The authors gratefully support all the anaesthesiologists of Cameroon, as well as all the authorities involved in this study.

Conflicts of Interest: The corresponding author confirms on behalf of all the authors that there have been no involvements that might raise the question of bias in the work reported or in the conclusions, implications, or opinions stated.

\section{References}

1. [Sickle Cell Disease International Organization (SCDIO)]—PubMed. Available online: https:// pubmed.ncbi.nlm.nih.gov/215206 48/ (accessed on 6 July 2021).

2. Khurmi, N.; Gorlin, A.; Misra, L. Perioperative Considerations for Patients with Sickle Cell Disease: A Narrative Review. Can. J. Anesth. 2017, 64, 860-869. [CrossRef] [PubMed]

3. Awa, H.M.; Dongmo, F.; Um, S.N.; Fonkwo, V.M.; Yanda, A.A.; Nlend, A.E.N.; Ndombo, P.O.K.; Tchokoteu, P.F. Aspects Épidémiologiques, Cliniques et Thérapeutiques des Crises Vaso-Occlusives chez les Enfants Drépanocytaires en Milieu Hospitalier à Yaoundé. Health Sci. Dis. 2017, 18, 89-97.

4. Firth, P.G.; Head, C.A.; Warltier, D.C. Sickle Cell Disease and Anesthesia. Anesthesiology 2004, 101, 766-785. [CrossRef]

5. Buck, J.; Casbard, A.; Llewelyn, C.; Johnson, T.; Davies, S.; Williamson, L. Preoperative Transfusion in Sickle Cell Disease: A Survey of Practice in England. Eur. J. Haematol. 2005, 75, 14-21. [CrossRef]

6. Muroni, M.; Loi, V.; Lionnet, F.; Girot, R.; Houry, S. Prophylactic Laparoscopic Cholecystectomy in Adult Sickle Cell Disease Patients with Cholelithiasis: A Prospective Cohort Study. Int. J. Surg. 2015, 22, 62-66. [CrossRef]

7. Fall, B.; Sagna, A.; Diop, P.S.; Faye, E.A.B.; Diagne, I.; Dia, A. La cholécystectomie laparoscopique dans la drépanocytose. Ann. De Chir. 2003, 128, 702-705. [CrossRef]

8. Dulvadestin, P.; Gilton, A.; Hernigou, P.; Marty, J. The Onset Time of Atracurium Is Prolonged in Patients with Sickle Cell Disease: Anesth. Analg. 2008, 107, 113-116. [CrossRef] [PubMed]

9. Rachid, S.; Didier, L.J; Badé, M.A.; Sani, C.M.; Habibou, A. Laparoscopic Cholecystectomy in Sickle Cell Patients in Niger. Pan Afr. Med. J 2009, 3, 19. [PubMed]

10. Badejo, O.; Idowu, O.; Balogun, J.; Shokunbi, W.; Amanor-Boadu, S.; Shokunbi, M. Outcome of Cranial Surgery in Nigerian Patients with Hemoglobinopathies: A Retrospective Study. Surg. Neurol. Int. 2019, 10, 16. [CrossRef] [PubMed]

11. I Constant Drépanocytose et Anesthésie. Conférences d'actualisation 1997; Elsevier: Paris, France, 1997; pp. 33-55. Available online: http://jpmiss2.free.fr/Divers/SFAR_2006/ca97/html/ca97_003/97_03.htm (accessed on 28 August 2020).

12. Al-Mulhim, A.S.; Al-Mulhim, F.M.; Al-Suwaiygh, A.A. The Role of Laparoscopic Cholecystectomy in the Management of Acute Cholecystitis in Patients with Sickle Cell Disease. Am. J. Surg. 2002, 183, 668-672. [CrossRef]

13. Al-Mulhim, A.S.; Al-Mulhim, A.A. Laparoscopic Cholecystectomy in 427 Adults with Sickle Cell Disease: A Single-Center Experience. Surg. Endosc. 2009, 23, 1599-1602. [CrossRef]

14. Vichinsky, E.P.; Neumayr, L.D.; Haberkern, C.; Earles, A.N.; Eckman, J.; Koshy, M.; Black, D.M. The Perioperative Complication Rate of Orthopedic Surgery in Sickle Cell Disease: Report of the National Sickle Cell Surgery Study Group. Am. J. Hematol. 1999, 62, 129-138. [CrossRef]

15. Leake, P.-A.; Reid, M.; Plummer, J. A Case Series of Cholecystectomy in Jamaican Sickle Cell Disease Patients-The Need for a New Strategy. Ann. Med. Surg. 2017, 15, 37-42. [CrossRef] 
16. Bhattacharyya, N.; Wayne, A.S.; Kevy, S.V.; Shamberger, R.C. Perioperative Management for Cholecystectomy in Sickle Cell Disease. J. Pediatric Surg. 1993, 28, 72-75. [CrossRef]

17. Chaussard, M.; Habibi, A.; Lobo, D.; Brunetti, F.; Galacteros, F.; Dhonneur, G.; Plaud, B. Cholécystotomies et syndromes drépanocytaires majeurs: Analyse des pratiques transfusionnelles et complications périopératoires. Ann. Françaises D’anesthésie Réanimation 2013, 32, A307. [CrossRef]

18. Goldsmith, J.C.; Wang, W.C. Preoperative Transfusion in Patients with Sickle-Cell Disease. Lancet 2013, 381, 886-888. [CrossRef]

19. Snyder, C.W.; Bludevich, B.M.; Gonzalez, R.; Danielson, P.D.; Chandler, N.M. Risk Factors for Complications after Abdominal Surgery in Children with Sickle Cell Disease. J. Pediatric Surg. 2021, 56, 711-716. [CrossRef]

20. Goodwin, S.R.; Haberkern, C.; Crawford, M.; Lerman, J.; Mancuso, T.; Yaster, M. Sickle Cell and Anesthesia: Do Not Abandon Well-Established Practices without Evidence. Anesthesiology 2005, 103, 205. [CrossRef]

21. Camous, J.; N'da, A.; Etienne-Julan, M.; Stéphan, F. Anesthetic Management of Pregnant Women with Sickle Cell Disease-Effect on Postnatal Sickling Complications. Can. J. Anesth. 2008, 55, 276-283. [CrossRef]

22. Bakri, M.H.; Ismail, E.A.; Ghanem, G.; Shokry, M. Spinal versus General Anesthesia for Cesarean Section in Patients with Sickle Cell Anemia. Korean J. Anesth. 2015, 68, 469-475. [CrossRef]

23. Griffin, T.C.; Buchanan, G.R. Elective Surgery in Children with Sickle Cell Disease without Preoperative Blood Transfusion. J. Pediatric Surg. 1993, 28, 681-685. [CrossRef]

24. Steinberg, M.H. Management of Sickle Cell Disease. N. Engl. J. Med. 1999, 340, 1021-1030. [CrossRef] [PubMed]

25. Mabiala-Babela, J. Le devenir des enfants atteints de drépanocytose homozygote traités par hydroxyurée à Brazzaville (Congo). Bull. Soc. Pathol. Exot. 2019, 112, 206-212. [CrossRef] [PubMed]

26. Brawley, O.W. National Institutes of Health Consensus Development Conference Statement: Hydroxyurea Treatment for Sickle Cell Disease. Ann. Intern Med. 2008, 148, 932. [CrossRef] [PubMed]

27. Al-Mulhim, A.S.; Alshehri, M.H. Laparoscopic Cholecystectomy in Adult Patients With Sickle Cell Disease. Surg. Laparosc. Endosc. Percutaneous Tech. 2012, 22, 454-458. [CrossRef] [PubMed]

28. Bonatsos, G.; Birbas, K.; Toutouzas, K.; Durakis, N. Laparoscopic Cholecystectomy in Adults with Sickle Cell Disease. Surg. Endosc. 2001, 15, 816-819. [CrossRef]

29. Currò, G.; Iapichino, G.; Lorenzini, C.; Palmeri, R.; Cucinotta, E. Laparoscopic Cholecystectomy in Children with Chronic Hemolytic Anemia: Is the Outcome Related to the Timing of the Procedure? Surg. Endosc. 2006, 20, 252-255. [CrossRef]

30. Al Talhi, Y.; Shirah, B.H.; Altowairqi, M.; Yousef, Y. Laparoscopic Cholecystectomy for Cholelithiasis in Children with Sickle Cell Disease. Clin. J. Gastroenterol. 2017, 10, 320-326. [CrossRef] 